\title{
The governments new career strategy: an end to placements for English Higher Education performing arts students?
}

\author{
David Hockham \\ University of Greenwich
}

This short article discusses the problems related to the scalability of placements in England for higher education (HE) institutions in a sector with limited economic resources: the performing arts.

Placements are an established part of learning vocational practice within HE (Guile and Lahiff, 2016, Little and Harvey 2006). The literature in this area notes that learning in educational settings is different from that of the workplace (Resnick, 1987), as learners in education identify as students rather than employees and establish and work within communities of practice for education rather than for industry (Lave and Wenger, 1991). This could mean that, post graduation, the difficulty experienced by graduates in navigating the transition between the learning environment and the workplace could result in a 'praxis shock' (Kvale, 1995, p.4). Placements are potentially a way of aiding students to navigate between these two communities of practice.

Historically, there have always been placements in theatres in England, taken by HE students to gain experience in the performing arts industry and supplement their in-course training. Before the school leaving age in England was raised to eighteen (DfE Department for Education, 2008), young people used to work for free to gain experience and then seek employment in this industry. This created opportunity for those with privilege: $94 \%$ of those employed in the performing arts in 2008 were white (CCSkills, 2008) and, whist the gender mix in the workforce was roughly equal, "women [were] likely to earn less money than their male counterparts" (CCSkills, 2010, p.10).

This unpaid labour raises ethical questions about workforce training delivery and the traditional workforce pipeline of university, unpaid internship and entry-level job. These considerations have led industry leaders to reject the practice of free labour. The London Theatre Consortium (LTC) notes:

"If we continue to recruit and train in the ways we always have, the demographic ... of our workforces will remain the same [having] a negative impact on our programming, our artistic and creative development, and mean that we fail to serve the communities in which we are based." (CCSkills, 2013, p.2)

The LTC, a consortium of thirteen of London's leading producing theatres, has had success in employing levels 2 and 3 apprentices who are paid the London Living Wage, now circa $£ 19,000$ (CCSkills, ibid.). This is higher than the average wage of a worker in Sheffield and has significant financial impact on what are often small organisations with tight budgetary considerations.

In the wake of post-16 compulsory education, the unskilled workforce has shrunk, meaning that people arrive now 'qualified,' wanting to undertake a management role rather than that 
of assistant (House of Lords, 2017). The government has attempted to respond - by changing the levels 2-3 training space while also attempting to resolve the 'skills gap' identified by employers - and deployed a national Career Strategy, published in December 2017 ('Careers strategy: making the most of everyone's skills and talents', 2017).

The new 'T levels' at level 3 are part of this strategy (students are able to opt to study a technical subject area rather than the standard $A$ level) and require students to do twenty to thirty hours of placement. Alongside this, the April 2017 arrival of the 'contemporary apprenticeship' has enabled apprentices from Levels 2-7 to learn on the job. However, such additional demand for work experience may well overload the placement system, to the detriment of students across the HE sector

There are, according to the Office of National Statistics, two million sixteen- to eighteenyear-olds in this country. If forty per cent of these students chose a vocational pathway and one per cent of these chose technical theatre, then 8,000 young people would need either thirty hours of placement or be on an apprenticeship every year. With only 1300 active theatres in the UK (TheatresTrust, 2018) - many of which not suitable for placements, as the figure includes pop-up and temporary venues, as well as school and college theatres - it appears that the needs of the 8000 young people and the number of placement places are irreconcilable. To add, on top of this, places for apprentices beyond eighteen years old at levels 4-7 and the HE institutional demand, is to confirm an apparently irresolvable problem.

There is an opportunity for English universities to re-think the workforce pipeline and to consider critically the ethical considerations about having young people work for free, with the twin aims of ensuring a workforce that represents the community it serves and of supporting students to navigate between education and the work place. This article marks the beginning of this author's journey to consider this.

\section{Reference list}

CCSkills (2008) Performing Arts: Impact and Footprint 2008/09. Purfleet, UK: Creative and Cultural Industries Ltd.

CCSkills (2010) The Performing Arts Blueprint. Purfleet, UK: Creative and Cultural Industries Ltd.

CCSkills (2013) Creative Employment Programme Case Study: London Theatre Consortium. Purfleet, UK: Creative and Cultural Industries Ltd.

Department of Education (2017) 'Careers strategy: making the most of everyone's skills and talents.' (December) Available at:

https://assets.publishing.service.gov.uk/government/uploads/system/uploads/attachment_da ta/file/664319/Careers_strategy.pdf (Accessed: 12 January 2018).

DFE (2008) Education and Skills Act 2008. London: Department for Education, p.144.

Guile, D. and Lahiff, A. (2016) 'Apprenticeship for "Liquid Life ": Learning in Contingent Work Conditions for Contingent Employment.' Vocations and Learning, 157-175. doi: 
10.1007/s12186-016-9166-3.

House of Lords (2017) 'Select Committee on Communcations. Corrected Oral Evidence: Skills for the theatre industry. 28 March 4.30pm' Available at:

http://data.parliament.uk/writtenevidence/committeeevidence.svc/evidencedocument/commu nications-committee/skills-for-the-theatre-industry/oral/49659.pdf (Accessed: 13 January 2018).

Kvale, S. (1995) 'An education rehabilitation of Apprenticeship learning.' American Eductaion Research Association.

Lave, J. and Wenger, E. (1991) Situate Learning: Legitimate peripheral participation.

Cambridge: Cambridge University Press.

Little, B. and Harvey, L. (2006) Learning Through Work Placements and Beyond A report for HECSU and the Higher Education Academy's Work Placements Organisation Forum.

Available at:

http://hecsu.ac.uk/assets/assets/documents/Learning_through_work_placements_and_beyo nd.pdf. (Accessed: 18 Oct 2018).

Resnick, L.B. (1987) 'Learning in school and out.' Educational Researcher, 16(9), 13-20. doi: 10.3102/0013189X029002004. Available at

https://people.ucsc.edu/ gwells/Files/Courses_Folder/ED\%20261\%20Papers/Resnick\%20In \%20\%26\%200ut\%20School.pdf (Accessed 13 January 2018).

TheatresTrust (2018) How many Theatres are there in the UK? Available at:

http://www.theatrestrust.org.uk/discover-theatres/theatre-faqs/167-how-many-theatres-arethere-in-the-uk (Accessed: 12 January 2018). 